\title{
Antiviral Agents: Discovery to Resistance
}

\author{
Catherine S. Adamson (D) \\ School of Biology, Biomedical Sciences Research Complex, University of St Andrews, St Andrews KY16 9ST, \\ Scotland, UK; csa21@st-andrews.ac.uk
}

Received: 3 April 2020; Accepted: 4 April 2020; Published: 7 April 2020

check for updates

In the midst of the SARS-CoV-2/Covid-19 outbreak the need for research into, and development of, antiviral agents is brought into sharp focus worldwide for scientists, governments and the public alike. This special issue includes primary research into new antiviral agents with activity against a range of clinically and economically important viruses. New antiviral strategies are discussed in six review articles.

SARS-CoV-2 is a newly emerged $\beta$-Coronavirus with sustained human-to-human transmission via the respiratory tract. Influenza viruses are another group of respiratory viruses, which account for 300-600 K deaths annually and represent an ever-present pandemic threat. Emergence of drug-resistant influenza strains is driving research into new anti-influenza drug candidates with different modes of action. In this issue, two papers report compounds with anti-influenza activity against a range of influenza A viruses that inhibit early steps in influenza replication not targeted by clinically approved anti-influenza drugs [1,2]. A further study reports that respiratory syncytial virus is inhibited in vitro and in vivo by natural product plant extracts in which phenolic glycoside acetoside was the active chemical component [3].

Drug resistance is an ongoing issue in the global rollout of combination antiretroviral therapy for human immunodeficiency virus (HIV) prevention and treatment. Tadesse et al. report the prevalence of pretreatment drug resistance among HIV-infected children in the resource-limited setting of Ethiopia [4]. Lectins are experimental HIV-1 entry inhibitors. Shahid et al. engineered the lectin microvirin to contain two carbohydrate-binding domains, this reduced its anti-HIV potency but anti-hepatitis C virus (HCV) activity was demonstrated [5]. Sherpa and Le Grice review recent research into the structural fluidity of the HIV Rev response element (RRE) and its potential as a target for therapeutic intervention [6].

Antiviral agents are not available against many emerging and neglected viruses. This issue features four research papers reporting new antiviral compound candidates against zika virus $[7,8]$, hantaan virus [9] and herpes B virus [10]. Measles virus is considered a re-emerging virus due to recent decline in vaccine coverage. Ferren et al. provide a comprehensive review on measles virus with a focus on central nervous system complications and the most advanced therapeutic approaches [11].

In addition to study into the zoonotic herpes B virus, this issue also includes two primary research papers investigating antiviral approaches targeting reactivation of latent herpesvirus infection. Anderson et al. demonstrated that the antipsychotic drug cloazapine inhibits epstein-barr virus (EBV) lytic reactivation [12]. In contrast, Chen et al. explore the potential application of genome-editing transcription activator-like effector nucleases (TALENs) against latent murine cytomegalovirus (CMV) infections [13]. The special issue also includes a review of the current antiviral strategies against human CMV [14] and a more focused review by Adamson and Nevels, which argues the case for the development of novel anti-CMV compounds by targeting major immediate-early (IE) gene expression or protein function [15]. RNA viruses can also establish persistent infections and this issue includes a study investigating the acquisition of drug resistance to fluoxetine during treatment of pancreatic cell-lines persistently infected with coxsackievirus B4 [16]. 
Research into antiviral agents against economically important animal viruses is also included in this issue, with three primary papers reporting antiviral agents with inhibitory activity against porcine circovirus type 2 (PCV2) [17] and porcine reproductive and respiratory syndrome virus (PRRSV) [18,19]. The study by Yu et al. demonstrates that antiviral effects of Ginsenoside Rg1 against PRRSV can be attributed to reductions in levels of host cell pro-inflammatory cytokines and suppression of NF- $k B$ signalling [18].

As mentioned, this special issue includes reviews into antiviral strategies against HIV, measles and CMV $[6,11,14,15]$. In addition, the issue contains reviews that discuss sphingolipids as potential therapeutic targets against enveloped human RNA viruses [20] and human antimicrobial peptides as therapeutics for viral infections [21].

Finally, I would like to thank all the authors, reviewers and editors, who made this issue possible, both at Viruses and in the wider academic community.

\section{References}

1. Ye, M.; Liao, Y.; Wu, L.; Qi, W.; Choudhry, N.; Liu, Y.; Chen, W.; Song, G.; Chen, J. An oleanolic acid derivative inhibits hemagglutinin-mediated entry of influenza a virus. Viruses 2020, 12, 225. [CrossRef] [PubMed]

2. Zhang, X.; Xia, Y.; Yang, L.; He, J.; Li, Y.; Xia, C. Brevilin a, a sesquiterpene lactone, inhibits the replication of influenza a virus in vitro and in vivo. Viruses 2019, 11, 835. [CrossRef] [PubMed]

3. Chathuranga, K.; Kim, M.S.; Lee, H.C.; Kim, T.H.; Kim, J.H.; Gayan Chathuranga, W.A.; Ekanayaka, P.; Wijerathne, H.; Cho, W.K.; Kim, H.I.; et al. Anti-respiratory syncytial virus activity of plantago asiatica and clerodendrum trichotomum extracts in vitro and in vivo. Viruses 2019, 11, 604. [CrossRef] [PubMed]

4. Tadesse, B.T.; Tsai, O.; Chala, A.; Chaka, T.E.; Eromo, T.; Lapointe, H.R.; Baraki, B.; Shahid, A.; Tadesse, S.; Makonnen, E.; et al. Prevalence and correlates of pre-treatment hiv drug resistance among hiv-infected children in ethiopia. Viruses 2019, 11, 877. [CrossRef]

5. Shahid, M.; Qadir, A.; Yang, J.; Ahmad, I.; Zahid, H.; Mirza, S.; Windisch, M.P.; Shahzad-Ul-Hussan, S. An engineered microvirin variant with identical structural domains potently inhibits human immunodeficiency virus and hepatitis c virus cellular entry. Viruses 2020, 12, 199. [CrossRef]

6. Sherpa, C.; Grice, S. Structural fluidity of the human immunodeficiency virus rev response element. Viruses 2020, 12, 86. [CrossRef]

7. Bernatchez, J.A.; Coste, M.; Beck, S.; Wells, G.A.; Luna, L.A.; Clark, A.E.; Zhu, Z.; Hecht, D.; Rich, J.N.; Sohl, C.D.; et al. Activity of selected nucleoside analogue protides against zika virus in human neural stem cells. Viruses 2019, 11, 365. [CrossRef]

8. Imran, M.; Saleemi, M.K.; Chen, Z.; Wang, X.; Zhou, D.; Li, Y.; Zhao, Z.; Zheng, B.; Li, Q.; Cao, S.; et al. Decanoyl-arg-val-lys-arg-chloromethylketone: An antiviral compound that acts against flaviviruses through the inhibition of furin-mediated prm cleavage. Viruses 2019, 11, 1011. [CrossRef]

9. Sanna, G.; Piras, S.; Madeddu, S.; Busonera, B.; Klempa, B.; Corona, P.; Ibba, R.; Murineddu, G.; Carta, A.; Loddo, R. 5,6-dichloro-2-phenyl-benzotriazoles: New potent inhibitors of orthohantavirus. Viruses 2020, 12, 122. [CrossRef]

10. LeCher, J.C.; Diep, N.; Krug, P.W.; Hilliard, J.K. Genistein has antiviral activity against herpes b virus and acts synergistically with antiviral treatments to reduce effective dose. Viruses 2019, 11, 499. [CrossRef]

11. Ferren, M.; Horvat, B.; Mathieu, C. Measles encephalitis: Towards new therapeutics. Viruses $2019,11$. [CrossRef] [PubMed]

12. Anderson, A.G.; Gaffy, C.B.; Weseli, J.R.; Gorres, K.L. Inhibition of epstein-barr virus lytic reactivation by the atypical antipsychotic drug clozapine. Viruses 2019, 11, 450. [CrossRef] [PubMed]

13. Chen, S.J.; Chen, Y.C. Potential application of talens against murine cytomegalovirus latent infections. Viruses 2019, 11, 414. [CrossRef] [PubMed]

14. Chen, S.J.; Wang, S.C.; Chen, Y.C. Antiviral agents as therapeutic strategies against cytomegalovirus infections. Viruses 2019, 12, 21. [CrossRef]

15. Adamson, C.S.; Nevels, M.M. Bright and early: Inhibiting human cytomegalovirus by targeting major immediate-early gene expression or protein function. Viruses 2020, 12, 110. [CrossRef] 
16. Alidjinou, E.K.; Bertin, A.; Sane, F.; Caloone, D.; Engelmann, I.; Hober, D. Emergence of fluoxetine-resistant variants during treatment of human pancreatic cell cultures persistently infected with coxsackievirus b4. Viruses 2019, 11, 486. [CrossRef]

17. Li, J.; Song, D.; Wang, S.; Dai, Y.; Zhou, J.; Gu, J. Antiviral effect of epigallocatechin gallate via impairing porcine circovirus type 2 attachment to host cell receptor. Viruses 2020, 12, 176. [CrossRef]

18. Yu, Z.Q.; Yi, H.Y.; Ma, J.; Wei, Y.F.; Cai, M.K.; Li, Q.; Qin, C.X.; Chen, Y.J.; Han, X.L.; Zhong, R.T.; et al. Ginsenoside rg1 suppresses type 2 prrsv infection via nf-kappab signaling pathway in vitro, and provides partial protection against hp-prrsv in piglet. Viruses 2019, 11, 1045. [CrossRef]

19. Wang, J.; Li, J.; Wang, N.; Ji, Q.; Li, M.; Nan, Y.; Zhou, E.M.; Zhang, Y.; Wu, C. The 40 kda linear polyethylenimine inhibits porcine reproductive and respiratory syndrome virus infection by blocking its attachment to permissive cells. Viruses 2019, 11, 876. [CrossRef]

20. Yager, E.J.; Konan, K.V. Sphingolipids as potential therapeutic targets against enveloped human rna viruses. Viruses 2019, 11, 912. [CrossRef]

21. Ahmed, A.; Siman-Tov, G.; Hall, G.; Bhalla, N.; Narayanan, A. Human antimicrobial peptides as therapeutics for viral infections. Viruses 2019, 11, 704. [CrossRef] [PubMed]

(C) 2020 by the author. Licensee MDPI, Basel, Switzerland. This article is an open access article distributed under the terms and conditions of the Creative Commons Attribution (CC BY) license (http://creativecommons.org/licenses/by/4.0/). 